\title{
Artelogie
}

Recherche sur les arts, le patrimoine et la littérature de l'Amérique latine

9| 2016

Horizons et perspectives de la culture en Colombie (1990-2015)

\section{Choc Quib Town and the performance of Afro Colombian identity}

Monica Gontovnik

\section{(2) OpenEdition \\ Journals}

Electronic version

URL: http://journals.openedition.org/artelogie/358

DOI: 10.4000/artelogie.358

ISSN: 2115-6395

Publisher

Association ESCAL

\section{Electronic reference}

Monica Gontovnik, "Choc Quib Town and the performance of Afro Colombian identity ", Artelogie [Online], 9 | 2016, Online since 20 June 2016, connection on 21 December 2020. URL : http:// journals.openedition.org/artelogie/358; DOI : https://doi.org/10.4000/artelogie.358

This text was automatically generated on 21 December 2020.

Association ESCAL 


\title{
Choc Quib Town and the performance of Afro Colombian identity
}

\author{
Monica Gontovnik
}

\section{Introduction}

1 This essay performs a textual analysis of three music videos posted on You Tube by Choc Quib Town, at the beginning of the career of a Colombian hip-hop group that is currently encountering national and international success. The analysis of words, sounds and images will be the guide in the journey toward understanding Choc Quib Town's artistic discourse pertaining to race. An art medium of this kind seems to be a privileged site of interrogation and of curiosity. Basic questions include: What are they saying? How do they construct their image as a Colombian Hip Hop group from the Pacific Coast? Why do they repeat certain types of images? What racial or ethnic identity is being constructed by their art making? Can this performance and construction teach us more about Colombia's plural-ethnic national identity? Colors, bodies, objects, costumes, beats, instruments show us the meaning of their performance. Anything speculated here would be the result of an inquiry into the specificity of their performance in these three specific videos.

\section{Naming}

When one is confronted with the name they have chosen for their musical artistic project, and the titles they have chosen for their songs, one can see that Choc Quib Town is asserting their intention for identity performance. So, let us start with a name: Choc: they belong to Chocó, a department of Colombia, a centralist Republic divided into thirty-two departments. Quib: points to their location in Quibdó, the main city of the Chocó Department. With the use of the English word Town they align themselves 
with the global youth movement that is hip-hop, born in the United States in New York in the 1970s.

3 The three videos published by Choc Quib Town at the beginning of their career towards national and international recognition, have, accordingly, titles that speak about identity. The first, Somos Pacifico (2008), roughly translates We are Pacific. Any Colombian would immediately understand the pun; they are really saying that they are from the Pacific Coast, even though they are also playing with being identified as pacifists in a country where violence is all-encompassing and where being black, poor and a rapper is associated with violence. Because they define themselves as artists, even without stating that they are pacifists, the connotation suggests that they have a seemingly innocent weapon: their songs. The second song and video is entitled De Donde Vengo Yo (2009). It translates exactly: Where I Come From, which plays again with their locality but at the same time with their cultural roots, the immaterial place of becoming. Colloquially, the phrase (de donde vengo yo) in Spanish can be used to indicate an emotional, a spiritual or intellectual point of departure. The third song, posted in April 2009, is simply titled Oro, Gold. Gold was one of the main reasons why African slaves were brought to Colombia. In Chocó, the largest and richest gold mines have been exploited since colonial times.

\section{Viewing}

\section{Global identity}

Hip hop has caught on as a performative identification tool for entire populations who see themselves facing the same problems as the black American culture that created it. In the first video, Somos Pacifico, we see a group of kids in a school classroom, sitting in uniform, using the hand movements that identify hip hop performance globally. They are saying the chorus lines of the song: la pinta, la raza, $y$ el don del sabor (the look, the race and the gift of flavor). In the second video, De Donde Vengo Yo, kids sing along and even do solos for the camera, as well as many amateurs, that is, those who are not performers. In the third video, Oro, kids' faces in close shots and many locals in their dwellings say the words of the chorus: "oro, oro te llevaste mi oro" (gold, gold, you have taken my gold). In the three videos analyzed for this essay, we can see children in different settings-in school, streets, houses, singing with the community in their choruses and attending football and basket ball games. This inclusion of the younger generation as well as the older in their videos signals something very akin to the beginnings of hip-hop in the USA ; it is the performance of blackness that has activated other performances across the globe in the last two decades. The words of one of its initiators, DJ Kool Herc point to the appeal of hip hop, as other cultures identify with the plight of blacks in the USA that gave rise to the hip hop movement in the seventies:

Come as you are." We are a family...It's about you and me, connecting one to one...It has given young people a way to understand their world...It brings white kids together with black kids, brown kids with yellow kids...the way you walk, the way you talk, the way you look, the way you communicate...It has become a powerful force. Hip-hop binds all of these people, all of these nationalities, all over the world together. (Chang, 2005: Intro)

5 In the 20-plus years since it emerged in inner city New York as an alternative to violence and a way to escape harsh urban realities, hip-hop has become a worldwide 
musical and cultural force (Stapleton, 1998). Hip-hop scholar Tricia Rose argues that "alternative local identities were forged in fashions and language, street names, and most important, in establishing neighborhood crews or posses" (Rose, 1994: 34). Fernando further claims, "Instead of always fighting with fists, hip-hop gave youth the option of fighting with words, art, dance or the ability to produce good beats" (1994).

6 I will argue here that even though one could read this as the trickling down of yet another cultural force from the United States of America to the South of the continent, the specific musical form that is the hip hop performance of Choc Quib Town, has managed to not only cultivate an art form that helps them understand their world, but that actively helps them pursue their identity construction as a form of resistance while infusing the medium with their own particularities.

\section{Locality}

7 In accordance with hip-hop history, Choc Quib Town territorializes their identity (Bennett, 2004: 197). Locality has always been important, since the inception of hiphop culture in the Bronx, New York (Forman, 2004: 202). Somos Pacifico, the first video addressed here, starts with the image of a body of water; we see the Atrato River, which flows through Chocó and whose shores define the border with the neighboring department of Antioquia. This river is navigated all the way to Quibdó and its path is a narrow valley between the Cordillera mountain range and the coast. It reaches the Atlantic Ocean and defines transportation and the economy of this region that is rich in water resources. Water will be a constant in the videos of Choc Quib Town. This area of Colombia is the world's rainiest lowland, with close to 400 hundred inches of annual precipitation. Much of the population thrives on fish, and their plentiful natural resources form a contradiction with the extremely poor living conditions of the majority of Chocó's population. Accordingly, in the opening of the Somos Pacifico video, we see a canoe; a man throwing a fishing net and a radio on the canoe later leads to a shot of a microphone and an announcer stating where we are located while listening. In De Donde Vengo Yo, we again are presented with the river-boats transporting people, fish being cleaned for sale-while in Oro the whole cast, singers and extras, sing with their legs deep in the water of a river where gold is being extracted.

8 In the group's first and third videos (Somos Pacifico and Oro), marimbas are showcased and traditional drums are shown. In the second video (De Donde Vengo Yo), trombones and trumpets accompany a carnival-like troupe of dancers dressed in golden costumes through the town's streets. In Oro, we are shown a traditional folkloric band playing for a group of dancers in the traditional white costume of the Currulao dance. These are not the instruments used in North American hip-hop. With their fusion of traditional sounds and hip hop sampling plus the rapping beat, they are telling the story of their identity. In an interview posted on their YouTube page, Band leader Carlos Valencia uses the artistic name Tostao, a pseudonym alluding to Toasting, the distinctive hip hop style of lyrical chanting (Samuels, 2004: 148) that is in direct lineage to the griots of West Africa (Tang, 2012: 80). In an interview posted on the group's YouTube page ${ }^{1}$, he states:

Choc Quib Town is a group that mixes traditional music from the Pacific Coast, like, Bunde, Currulao, Bambazu, Levantapolvo, with elements of hip hop, dancehall and funky, besides the strong element of salsa which identifies Latino music around the 
world.... we are from the Africa that is inside Colombia, where all the prietos (dark skinned) live... ${ }^{2}$

As Valencia states, the group members belong to a region in Colombia where the highest percentages of the black population live. The rappers were childhood friends who met in Cali many years later and then moved to Bogotá, the capital of Colombia, where there are more opportunities for emerging artists. They all worked in other groups that were already professionalized. Tostao played with Mojarra Eléctrica, an experimental jazz-funk-folk band. Goyo (pseudonym for Gloria Martinez), originally from Condotó, sang with Sidestepper, an experimental electronic-folk fusion band. The group managed to get together money to assemble their own little studio and record their first $\mathrm{CD}$, which they distributed themselves. Rappers in Colombia, in general, see themselves as a social movement. This is a characteristic of the Colombian hip-hop movement, one done in all the cities as voice for marginalized barrios of the main cities (Feiling, 2005). As such, many revel in bypassing the industrialization system (Dennis, 2008: 190-91).

10 As the video Somos Pacifico progresses, we see groups of folk dancers in their attire: colorful clothes worn in the Pacific region of Colombia. The dances and songs, still performed today, are the ones that the slaves developed while in contact with the white and indigenous cultures around them. Dances like Currulao, Aguabajo, Arrullo, Bunde, Bambara, and the Jota are visual clues to the heritage Choc Quib Town needs to accent, because the group talks about their history in this very specific part of Colombia. A common view about the music and dance from Colombia is stated in a way that accents the tri-ethnic mixing of the national identity:

11 The Spaniards brought the quadrille, danza, contradanza, and other dances. These were adopted by the Indians and the Negros but in the assimilation each race chose what was most in accord with its own preference in kinesthetic expression and introduced into them elements of their own folklore, thus creating new, hybrid forms. In some regions the mixture of all three races gave rise to a third type of folk dance, tri-ethnic in character, thus increasing the gamut of ancestral patrimony. (Zapata Olivella, 1967: 92) In Somos Pacifico, a group of men and women in costumes pose as if for a photograph in front of a huge door of a building that seems to be a church. They sing and move to the chorus (Somos pacífico, estamos unidos/ We are pacific, we are united/ Nos une la región/ United by the region/ La pinta, la raza y el don del sabor The look, the race and the gift of flavor). The door opens; the group moves aside, and the lead singer of the following rap lines emerges through the doors. She is Goyo, a young woman dressed in a contemporary way that signals her identification with blackness in the country of Colombia: a bright wraparound headscarf, bright yellow short dress and tights. She sings to the camera, to us. The next scene is of her in a balcony where the wooden walls and frames of door and veranda match the colors she is wearing. In the balcony with her, continuing her song, a group of folkloric dancers join in the singing and moving. With both scenes that interpolate folk attire and contemporary ones, they connect the very hip female singer, and thus the whole group, to a sense of pride in their ethnic heritage. In De Donde Vengo Yo, carnival dancers in golden costumes are portrayed as they parade in the center of the town and what looks like a Chirimia band plays; here they use brass instruments like bombardino, clarinet and drums. In Oro, Goyo first appears in the muddy waters dressed as a miner and later in very contemporary clothes singing with children and other adults from the town. In this video, at the end, 
we see staged scenes of contemporary dancers in African-like vestments that portray a desire to dwell in their African ancestry.

\section{Ethnicity}

13 Colombia has the third largest black population after Brazil and the US, but this is hardly acknowledged, since during the colonization the nation was constructed under an image of "colombianity" without racial differences and under the spell of mestizaje. This is a term promoted by the Colombian state since 1851, a term aiming at the whitening of the black population with the intention of erasing the signs of difference. A whole culture idealizing the mixed but not fixed race of Colombia in any color is still functioning in actuality:

Blacks and especially indians were romanticized as part of a more or less glorious past, but the future held for them paternalistic guidance towards integration, which also ideally meant more race mixture and perhaps the erasure of blackness and indianness from the nation. The mestizo was idealized as of bi-ethnic or triethnic origin, but the image held up was always at the lighter end of the mestizo spectrum. (Wade, 1993: 11)

14 A national identity was thus formed in the pride of a tri-ethnic heritage: white, black and indian. The idea of a nation built on mestizaje with no separate ethnic populations or races, is one of the reasons the black and indigenous populations tend to be geographically located and separated which at the same time makes them very vulnerable to becoming the targets of continued displacement from their lands as successive appropriation by powerful groups for their use in coffee, banana, sugar cane, oil palm and cocaine plantations occur. Traditionally the "indian" or indigenous population has been identified as a people in need of protection, as a minority that has been in continuous danger since the conquest. They have been granted land protection (on paper, because in reality they are continually displaced as their lands are needed for exploitation) and have gained many rights, especially since the last constitutional reform of 1991. The black population of Colombia has not been viewed in the same way, since they were brought to the Americas from different places in Africa by the conquistadores for the exploitation of their labor. According to the State, they do not have any real ancestral right to the land, since they were immigrants. From this assumption we can infer how difficult the situation has been for this minority, forever in limbo, not belonging to any land, not even the one where they were born. But, also in the last two decades, they have formed political clusters that have gained recognition as an ethnic group that has lived in areas like Chocó for generations and thus deserves to be treated according to their ancestral rights to the same. In order to do this, they have had to copy the political strategies of the indigenous minorities, sometimes even to gain representation through them and develop a new discourse that points to an "ethnicity," that of Afro-Colombianity, which has allowed the process of visibility (Friedemman, 1995).

15 At the end of Oro phantom images of black contemporary African-like dancers, their bodies painted with pre-Columbian designs, appear in the mountainous background where Goyo is singing. The song closes with an image of an archeological gold piece from the Colombian Gold Museum. This image indicates alliance with the indigenous peoples of the land who also suffer displacement whenever a powerful entity needs their land for exploitation in the name of "progress" for the whole nation. In the 
context of the displacement that black communities suffer in Colombia, Chomsky writes, "Gold motivated the first large-scale displacement of Africans of Portuguese, Spanish, and British slave ships, to the Pacific Coast regions of Colombia" (2007: 173). Chomsky explains how these communities of descendants of the first slaves have been continually forced from their lands in order to accommodate mining when resources are depleted. The ideology of racial difference developed in the fifteenth century enabled the Europeans to justify continued exploitation with a "scientific" dogma that still permeates the modern nations formed after colonization including Colombia (2007: 173).

16 This ideology Chomsky refers to is again that of mestizaje, leading to the contemplation of yet another odd visual feature in that also points to political representation in Colombian racial and ethnic history. It is just as odd as the gold pre-Columbian piece at the end of the Oro video. Why would these artists introduce discursive elements of an ethnicity other than their own? This odd visual image in the video De Donde Vengo Yo (Where I Come From) is the appearance of an indigenous woman in her ethnic dress, dancing with a crowd of black people next to the lead female rapper, who embraces her. As the multitude dances, she sings "De donde vengo yo la cosa no es fácil pero siempre igual sobrevivimos." (Where I come from it is not easy but all the same we survive). This is an odd feature because it is the only image of an indigenous person-otherwise, all we see in the three videos are people who can be identified as natives of Chocó, a vastly black population. The indigenous woman wears a dress that identifies her as part of the Embera tribe. The Embera people reside in the Darien region, a zone that used to be part of Colombia and the Chocó department but which is now part of Panamá. Now we know that they used the political strategies of the various indigenous tribes of Colombia, who had an older tradition of using those strategies in order to protect their rights to land and culture (Fals Borda, 1992). It becomes even more interesting to learn that this image is a direct reference to the fact that when the Afro-Colombians had no political representation rights as a minority in the ANC (National Constitutional Assembly), they managed to ally with the Embera constituent Francisco Rojas Birry, on the condition that he would also defend the Afro Colombian population and support the projects that would favor their claims (Hurtado, 2000).

\section{Resistance}

When the chorus of the song Somos Pacifico is again in the part that talks about unity related to race, color and flavor, we see the three rappers Goyo, Tostao and Slow walking down a public open market place, with people saluting and joining them. The three wear what can be identified as global hip-hop clothes, with a woman leading as they rap and are joined in the chorus. Their clothes, the dances and their hand gestures help identify their performance with the carnivalesque, as defined by Bakhtin (1968) who believes that the market place is a privileged site for celebration, for promoting the erasure of separateness and for types of communication not possible in everyday lives. The dance costumes in the three videos are also a clue directing the viewer to the same interpretation because they relate to the carnival festivities that take place in many Colombian cities and towns. These festivities always include regional dances and music that are the development of the purported mixing of the performance elements of the three races. Appearing inside the visual structure of a video perceived as a very contemporary hip hop performance, these images are definitely a wink to the group's 
racial heritage, to their place in the mixed nationality and to the function of the carnivalesque so well described by Bakhtin. Carnival clothes, carnival dances that come from a folk heritage, dancing in the streets, hand gestures and words that belong to the global hip hop movement all corroborate this idea. These hand gestures, although alien to local inhabitants of Chocó, akin to the global movement, are also part of the carnivalesque function, the resistance function of global hip hop.

..... TT]he carnival-grotesque form exercises the same function: to consecrate inventive freedom....to liberate from the prevailing point of view of the world, from convention and established truths, from clichés...carnival spirit offers the chance to have a new outlook on the world, to realize the relative nature of all that exists, and to enter a completely new order of things. (Bakhtin, 1968: 34)

Choc Quib Town intends to subvert the order of things, as they should for a young group of Afro Colombians in the twenty first century, and at the same time, they are also honoring their two lineages: one that talks about the distant past, tracing back to the development of folk music and dance, and the other related to the immediate past, that of their attachment to hip-hop as a global youth movement. Dress is an important part of their identity performance. We see them dress according to the different mise en scenes: they are rappers, they are a soccer team, they are miners, motorcyclists, "regulars," etc. As Fanon (1997) states,

The way people clothe themselves, together with the traditions of dress and finery that custom implies, constitutes the most distinctive form of society's uniqueness, that is to say the one that is the most immediately perceptible...fact of belonging to a given cultural group is usually revealed by clothing traditions. (259)

The rappers who walk in the market during Somos Pacifico open the path to Tostao's lyrics. Standing among a group of young black people who stare ahead seriously in the middle of a street, he raps the beginning of his strophe: unidos por siempre (united for ever) while we watch this silent group. He continues the song in various urban places: a basketball court where he will later be joined by kids, a dilapidated wall and then an open-air concert where rain pours down on him and on the audience. Urban spaces conflate with rural places, with the river, vegetation, towns and roads. Slowly, the third rapper says his lines as a woman inside a typical "Chocoan" home braids his hair. He later appears on a motorcycle, followed by a group of cyclers. Here the camera is in front of them as they advance through the streets and there are cuts to him singing on stage of the same concert where rain is pouring on the audience. Motorcycles are a clear reference to the media of transportation that is most accessible to populations that do not have enough money to own a car (in Colombia a car is a signifier of social status since they are highly taxed and very expensive) or that have to travel roads more easily accessible by this type of transportation. In De Donde Vengo Yo, this text is rapped by Tostao: “...everyone who has nothing uses rapi-moto...uncovered roads to travel..."

In actuality Colombia has developed a very interesting transportation alternative that is a non-official activity that has been targeted by bus and taxi owners in order to stop it. Nonetheless, this medium thrives on popular demand: it is called mototaxism. The choice to forefront motorcycles in their video is a way of identifying with the people and their chosen ways of getting away with not following the rules of an economy that eats all of their earned money in everyday normal activities. Moto-taxi drivers are usually unemployed or under-employed men who get hold of or rent motorcycles and 
transport anyone for a low price. They have been involved in many riots and incidents with the police in the last five years, as attested by the following newspaper article:

Motorcycles are destroying public transportation in medium-sized cities. For example, in 2003 in Sucre, there were 260 public transportation vehicles. In 2004, that dropped to 241 and in 2007-it fell further to 180 . In contrast, the number of motorcycles is growing at alarming rates. In 2003 there were 1,724. In 2007 that figure grew to $9,705 . .$. Moto-taxis are dangers in terms of security and in addition they exclude children, the elderly and persons with physical disabilities. "The motorcycle is a viable option if it is used for one person, but not as public transportation," the report states ("Columbia on the verge," 2008).

During the first video Choc Quib Town published, as the third rapper finishes the line he had started on the motorcycle ride, he raps: Because Colombia is more than marihuana, coca and café. There is a cut back to him on stage and then just silence. This is the end of the concert, the end of the song and the end of the video. They have, for the first time, with this last line of lyrics, located themselves in the country of Colombia (although to a Colombian hearing the song it is obvious that their City is in the country.) Not only do they use a phrase that seems completely out of place with the rest of the song, but through it they assert that the country is more than these products that bring money and a bad name: the country is made of people like them, the ones who want to be visible, once and for all-the black people who populate the Pacific Coast of Colombia. They are in excess, they are the forgotten ones, but they are proud of their racial heritage:

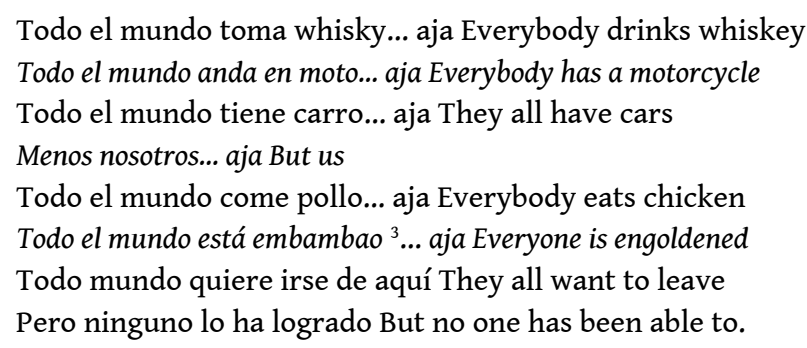

Us, nosotros-we are the forgotten ones, the ones located in this part of Colombia; we have less, and we are in excess. It is an excess that Choc Quib Town gladly sings about, as they have learned to embrace it, to own it and now, to enjoy it: "De la zona de los rapi mami papi/ Tenemos problemas pero andamos happy" (From the Zone of Rapi, Mami, Papi, We have problems but we are happy.)

The group plays with the slang word embambao, a Colombian slang term referring to someone who possesses and wears a lot of gold, the sign of wealth native to their land yet alien to those who live in poverty. Gold, one of the region's riches, was plentiful and even excessive at one time, though now not so much, after constant exploitation. Gloria, the lead rapper in Choc Quib Town, is from Condoto (Ramirez, 2006) the richest mining region of Chocó. In "Oro," the group becomes more overtly political and even more local in their musical sound, with fewer rap beats and lines. The images in the video talk of rebellion and assurance of power over the exploiters. Mining and wood exploitation are powerful forces of displacement in the country. As soon as the department of Chocó was created, the efforts of the black population to create their own independent exploitation of the natural resources were curtailed and boycotted by the national government. The pattern of state abandonment and continued displacement and impoverishment of the population has continued until today, despite 
the Constitution of 1991 (Friedemann, 1993). In their second video, they have already begun to say things like

Invisibilidad nacional e internacional National and international invisibility

Auto-discriminación sin razón Self-discrimination without reason

Racismo inminente mucha corrupción Imminent racism, much corruption

Monte culebra Woodland snake

Máquina de guerra War machine

Desplazamientos por intereses en la tierra Displacements due to land

interests

In Oro (Gold) Gloria tells us in song that someone came to her land who took all her gold, that he was dressed in white and had a foreign accent. He promised money in exchange, but he took everything away with him and he never came back. She calls him "thief" as the chorus is sung by the miners in the scene and later repeated by children, older adults and local people throughout the song. In this video Tostao raps his lines and only then, we the audience, realize that he is one of the miners. He has abandoned his rapper's garb and flows directly to the man who is here obviously a mestizo watching the sifting soil from above, from where the camera is placed, showing the lower position of the miners: "Go away, away from here papa, you will not steal again, go with your mirrors, thief." Goyo continues with the sentiment, "From here I will not go, this is my land, my soul is like the river, it knows many roads..."

Mining here again speaks of identity, history, the pain of invisibility and the trauma of displacement and disenfranchisement, but with the intention to subvert this state of things with joy and pride. The music and movements are not sad; they are playful, joyful and assertive. Since the intended audience is the Colombian population as a whole, with this song that talks about the particularity of gold mining, they are, in a sense, giving an example of how locality should be a mirror for the other regions of Colombia: the protection of natural resources from foreign exploitation is an urgent political issue.

\section{Visibility}

Visibility is one sure thing Choc Quib Town desires. In the interview posted on YouTube, Goyo, the female lead singer of Choc Quib Town, is emphatic about her art, in part, being a response to the need to make her region of the country visible: "People don't know that the Pacific exists. Many people did not know and now, with us, they know that our music can be mixed with other rhythms that are not from here, because our music is rich and multiple with many rhythms and sonorities." ${ }^{4}$ Some residents of Chocó, like these artists, need to leave poverty behind and move to capital cities of other departments, like Cali, Bogota and Medellin. Others less fortunate must leave due to the on-going violence that usually comes too near their lands, vulnerable as big companies move in to exploit their resources.

One image that is puzzling in the second video, Where I Come From, speaks to this. It could be puzzling to audiences who are not familiar with Colombian racist history. These images can be confounded with ways of commodification of black women. In this scene, we see images of young black girls who appear to be getting ready for a beauty contest. We see them applying makeup, posing in bathing suits, aligned. These are not the typical women's images that we see in hip-hop video, where masculinity is displayed as a foil against sexy objectified women. These young girls are not playing the 
role of sexy, they are not displayed as a background against the males; they are entering beauty contests, almost innocently, watching us, the observers. Why? Colombia's National Beauty Contest is an event celebrated every 11th of November, the date that also marks the revolt in Cartagena against the Spanish colonizers in 1811. Since the nineteenth century this date has been celebrated with a catholic mass and a parade presided by "a goddess of freedom." In the twentieth century the celebration mutated, becoming a National Beauty Contest that lasts a whole week, a carnivalesque celebration that becomes a big partying occasion in Cartagena, with the whole country anxiously watching every one of the contestants' moves. Since this pageant was established in 1934, it has captured the public's imagination. The country is immobilized, watching every move each regional department's contestant takes while competing for the crown. Pride in each department bursts when a girl is elected from a specific region, and the following reception in her hometown also becomes a holiday. In November 2001, ten years after the blacks in Colombia were awarded representational rights in the Constitution as an ethnic minority, for the first time in the contest's history, a black woman was elected the National Beauty Queen of Colombia. It is ironic that Cartagena, the city on the Atlantic Coast where the contest takes place, also has one of the largest concentrations of black citizens in the country. For decades the contest had been called racist because no black woman could earn the crown, even though many times they were obviously the most beautiful or popular. Colombia was not ready to accept such recognition for a black woman. In 2001 Vanessa Mendoza from Chocó promised her people to use her term as queen to call attention to their forgotten department. She also wanted visibility for her region. When she arrived home after the competition, the party went on for several days. The rappers who made this video in order to showcase their song about pride in their identity would have been about ten or twelve years old at this time. De Donde Vengo Yo, uses these images to remind the impoverished young girls of the Chocó region that they too are as beautiful as Gloria (Goyo) the singer and Vanessa, that they should be proud of the racial markings of their skin if that is how they are being defined by in a country where the lighter you are, the less black you become. Accordingly, in the video Somos Pacifico, two black women display their beauty, always appearing in bathing suits that show their skin, with very sensuous movements. In Colombia, these movements are identified with black dances developed by the descendants of the African slaves who escaped or bought their freedom and managed to build their own communities, settling in palenques where they kept a lot of their culture intact. These are not the sexual images that we tend to encounter in mainstream rap from the U.S. now. In these bodies of beautiful women they are placing racial pride. Pride in being black is somehow new in Colombia after centuries of marginalization, despite the discourse of mestizo, tri-ethnic official nationality, a discourse which has not stopped racial prejudice that regards lighter shades of skin as signals of desirability and upward class mobility.

When Colombia's constitution was revised in 1991, the country's diverse ethnic groups were given legal access to representation in the Congress and Senate. Even though the Constitution of 1991 recognizes the black population as a main component of Colombian society, the majority of this population still lives in poverty, suffers discrimination and endures forced displacement. Only about ten percent of Colombians see themselves as Afro-Colombian, but about thirty percent of the Colombian population has an African heritage. Visibility is something that the black population has been striving for since then, within a frame of supposed governmental inclusion. 
These efforts have culminated in events such as the naming of Paola Marcela Moreno as the first black Minister of Culture in 2007, a young woman born in Chocó who holds a degree in industrial engineering and a master from Cambridge University. In 2006, General Luis Alberto Moore was the first Afro-Colombian to be elected as Chief of Police of the third most important city in Colombia, Cali. In 190 years of Republican history, only three ministers, a vice-minister and a temporary president (in 1861) have been black (Salazar, 2007). In 2001 a federal law (Ley 725 de 2001) established the month of May as the National Afro-Colombianity Day in order to honor the objectives of the construction of a historical memory. This is in accordance with the promulgated Law 70 of 1993 that recognizes black communities as ancestral holders of the lands of Chocó, where they have formed communities since the 1800 s and as such are under the protection of the State. Furthermore, Decree 1320 of 1998 states that the Afro Colombian community must be consulted whenever their territories' natural resources might be exploited. Springing from Chocó, Choc Quib Town is part of a whole Afro Colombian movement for increased national participation as full-fledged citizens.

\section{Conclusion}

Choc Quib Town has chosen a very distinct way of making music, one that blends their locality with the global appeal that hip hop has for young people around the world who perceive themselves as marginalized. Doing their art, performing on stage nationally and now internationally and posting their video clips on the You Tube website is their way of producing a new identity in accordance with the times in which they live. While doing their art they can express pride in their racial heritage, their African ancestry, their multi-ethnic nationality and their natural resources in a land that has now been gained as a political right. The more visible they are, the more they can sing against racism, marginalization, poverty and displacement. They have chosen to reiterate their pride in what could be perceived as an essentializing racial discourse, but they also showcase all the traits that are particular to their location in time and space in order to resist though pride and self-determination. They determine who they are, they construct their own image and they contribute to their people's identity, hopefully a strong one that will be able to stand against injustice. This injustice is long overdue for a reckoning in order to truly embrace the tri-ethnic composition of the Colombian nation. If art can empower, this is surely one example of the power that comes through claiming one's whole identity-locality, history and race. At this moment, almost a decade later, one can see with preoccupation that Choc Quib Town has merged into mainstream and with increased notoriety, popularity and wealth, their lyrics and sounds have changed. The fact that capitalism has managed, yet again, to digest and tame subversive identity in artistic performances, should be the subject of further studies into Choc Quib Town's trajectory. For now, one can only hope to remember their beginnings as superb performers of Afro Colombian identity. 


\section{BIBLIOGRAPHY}

BAKHTIN Mikhail. Rabelais and His World. Transl. Helene Iswolsky. Cambridge, Mass: MIT Press, 1968.

BENNETT Andy. "Hip-Hop am Main: Hip-Hop Culture as a Local Construct in Two European Cities." That's The Joint !: The Hip Hop Studies Reader. Ed. Murray Forman and Mark Anthony Neal, New York: Routledge, 2004. 177-200.

CHANG Jeff. Can't Stop, Won't Stop: A History of the Hip-hop Generation. New York: St. Martin's Press, 2005.

CHOMSKY Aviva. "The Logic of Displacement: Afro Colombians and the War in

Colombia." Ed. Darien J Davis. Beyond Slavery: The Multilayered Legacy of

Africans in Latin America and the Caribbean. Lanham, MD: Rowman \&

Littlefield, 2007. 171-198.

"Colombia on the Verge of a Monumental Traffic Jam." (2008). Semana, Bogota. http:// www.semana.com/noticias-print-edition/colombia-on-the-verge-of-monumental-traffic-jam/ 117659.aspx

DENNIS Christopher, "The 'Afro-Colombianization' of Hip-Hop and Discourses on Authenticity." Postnational Musical Identities: Cultural Production, Distribution, and Consumption in a Globalized Scenario. Ed. Ignacio Corona and Alejandro L. Madrid. Boulder: Rowman \& Littlefield, 2008. 185-207.

FALS BORDA, Orlando. "Social Movements and Political Power in Latin America". The Making of Social Movements in Latin America: Identity, Strategy and Democracy. Arturo Escobar and Soni Alvarez, Eds. Boulder: Westview Press, 1992. 303-316.

FANON Frantz. "Algeria Unveiled." Mimesis, Masochism \& Mime: The Politics of Theatricality in Contemporary French Thought. Timothy Murray, Ed. Ann Arbor: University of Michigan Press, 1997. 259-274.

FEILING Tom. Resistencia: hip-hop in Colombia. New York: Faction Films, 2005. Digital Video.

FERNANDO S. H. The New Beats: Exploring the Music, Culture, and Attitudes of Hip-Hop Culture. New York: Harmony Books, 1994.

FORMAN Murray. "Represent: Race, Space, and Place in Rap Music." That's The Joint !: The Hip Hop Studies Reader. Ed. Forman, Murray and Mark Anthony Neal, New York: Routledge, 2004. 201-222. FRIEDEMANN Nina. La Saga del Negro: Presencia Africana en Colombia. Santa Fé de Bogotá: Instituto de Genética Humana, Facultad de Medicina, PontificiaUniversidad Javeriana, 1993.

HURTADO Teodora. Politica y Movimiento Social Agrario en un Contexto de Transformacion de Comunidades Negras Semirurales. (Informe de avance de proyecto). Program de becas CLACSO, 2002. Accesed Nov 9, 2009.bibliotecavirtual.clacso.org.ar/ar/libros/becas/2000/hurtado.pdf

RAMIREZ L. (2006). “Cantadoras de la nueva generacion” El Tiempo, Bogota. http:// www.eltiempo.com/archivo/documento/MAM-2282954

ROSE T. Black Noise: Rap and black culture in contemporary America. Hanover NH: Wesleyan University Press, 1994. 
SALAZAR H. “Colombia hacia la integracion social?" (2007). BBCMundo.com, Bogota.http:// news.bbc.co.uk/hi/spanish/latin_america/newsid_6691000/6691309.stm

SAmuels David. “The Rap on Rap: The "Black Music” that Isn't Either.” That's The Joint !: The Hip Hop Studies Reader. Ed. Murray Forman and Mark Anthony Neal. New York: Routledge, 2004. 147-153.

STAPLETON Katina R. (1998). "From the Margins to Mainstream: The Political Power of HipHop." Media, Culture \& Society 20: 219-234.

TANG Patricia. “The Rapper as Modern Griot: Reclaiming Ancient Traditions." Hip Hop Africa: New African Music in a Globalizing World." Ed. Eric Cherry. Bloomington: Indiana University Press, 2012. 79-91.

WADE Peter. Blackness and race mixture: the dynamics of racial identity in Colombia. Baltimore: Johns Hopkins University Press, 1993. Print.

ZAPATA Olivella, Delia. “An Introduction to the Folk Dances of Colombia.

Ethnomusicology 11.1 (1967): 91-96.

\section{Songs and videos}

Somos Pacifico

http://www.youtube.com/watch?v=fjx5fg2pvFs

De Donde Vengo Yo

http://www.youtube.com/watch?v=yb_jD-Yfp4\&NR=1

Oro

\section{NOTES}

1. These videos can be accessed on YouTube at http://www.youtube.com/user/ ChocQuibTown\#p/u/8/TAtOw8DHpDM

2. All translations of Choc Quib Town lyrics in this article are my own.

3. This Colombian slang term refers to a person who wears an excess of gold jewelry, to display his or her wealth.

4. My translation.

\section{ABSTRACTS}

This essay examines the work of the Colombia Hip Hop group called Choc Quib Town at the beginning of their career. In order to do so, three videos published between 2008 and 2009 are analyzed. These three videos show their desire for an performance that showcases their Afro Colombian identity that at the same time finds a way to vindicate the rights of this ethnicity to have a dignified and proud entry into Colombian mainstream. Their lyrics and images as seen in this virtual platform is a form of protest that deepens our understanding of the inequalities still suffered in the Chocó region of Colombia. 
Cet article étudie le travail du groupe de musique hip-hop colombien nommé Choc Quib Town au début de sa carrière. Nous allons prendre en compte trois vidéoclips du groupe publiés sur YouTube entre 2008 et 2009. Ces vidéos montrent le désir d'une performance d'identité afrocolombienne qui, en même temps, cherche à établir une revendication des droits pour une vie digne, vraiment insérée dans la nationalité colombienne. Les paroles et images de la plateforme virtuelle nous permettent de comprendre le message du groupe comme une proteste pacifique et édificatrice qui néanmoins approfondie dans la plupart des iniquités notre compréhension des inégalités encore subies dans la région du Pacifique colombien, le département du Chocó.

\section{INDEX}

Mots-clés: identité, performance, afro-colombianité, hip-hop, ethnicité

Keywords: identity, performance, afrocolombianity, hip hop, ethnicity

\section{AUTHOR}

\section{MONICA GONTOVNIK}

PhD Interdisciplinary Arts. Universidad del Norte, Barranquilla, Colombia. Departamento de Humanidades y Filosofía.

Her dissertation research centered on Colombian contemporary women artists. Her other degrees are: Contemporary Philosophy Specialization, Universidad del Norte (2005) ; Master of Interdisciplinary Studies in Arts and Psychology from Naropa University (2001); Bachelor of Science in Dance from Skidmore University Without Walls (1980). Monica writes an opinion column at El Heraldo, the main newspaper of the Colombian North Coast. Monica is a performer and a poet who created and directed Kore, a pioneer dance-theatre company form 1982-1997. She has published seven poetry books and is actually working on editing a novel. 